Conference Proceedings Paper - 1st International Electronic Conference on Molecular Science: Cell Signaling, Survival and Growth

\title{
Photodynamic Antimicrobial Chemotherapy, A Pathway for Photo-Inactivation of Bacteria by Porphyrin Compounds
}

\section{Fatemeh Fayyaz ${ }^{1, *, \dagger}$, Rahmatollah Rahimi ${ }^{1, \dagger}$, Mehdi Rassa ${ }^{2, \dagger}$ and Reza Hedayat Yaghoobi ${ }^{3, \dagger}$}

1 Bioinorganic Chemistry Laboratory, Department of Chemistry, Iran University of Science and Technology, Tehran 16846-13114, Iran; E-Mail: rahimi_rah@iust.ac.ir

2 Department of Biology, Faculty of Science, University of Guilan, Rasht, Iran;

E-Mail: rassa9@yahoo.com

3 Medical University of Kermanshah, Kermanshah, Iran; E-Mail: rhy824@yahoo.com

$\dagger$ These authors contributed equally to this work.

* Author to whom correspondence should be addressed; E-Mail: f.fayyaz@yahoo.com; Tel: +98-21-7724-0290; Fax: +98-21-7749-1204.

Received: 21 July 2015 / Published: 16 October 2015

\begin{abstract}
Photodynamic antimicrobial chemotherapy is a pathway for consideration of cell death of many microorganisms in biology such as bacteria. Various photo-sensitizer compounds were used in this technique such as porphyrin compounds. In this work, the effect of various concentrations of cationic porphyrin compounds was investigated and compared on cell death of $S$. aureus and E. coli by means of a 100 watt tungsten lamp.
\end{abstract}

Keywords: E. coli; photo-bactericidal; photodynamic antimicrobial chemotherapy; S. aureus; tetra-cationic porphyrin

\section{Introduction}

Photodynamic therapy (PDT) is a process in which the photo-sensitizers by light energy results in the production of cytotoxic singlet oxygen and free radicals. The activity of these cytotoxic compounds is selective and dependent on the delivery of the photo-sensitizer to the target samples [1].

Also, photodynamic antimicrobial chemotherapy (PACT) is a developed remedial option to induce oxidative damage to microbial pathogens [2-5]. 
This method utilizes photo-sensitizers and visible or ultraviolet light in order to give a phototoxic response, normally via oxidative damage. Currently, the major use of PACT is in the disinfection of blood products, particularly for viral inactivation, although more clinically-based protocols are being developed, e.g. in the treatment of oral infection [6].

Gram positive bacteria such as $S$. aureus are one of oral infections and could to be susceptible to the activated compounds. But, activity against gram-negative bacteria was limited to instances in which outer membrane permeability was achieved through the use of membrane-active agents [1].

Porphyrin compounds have significant potential as photo-remedical factors for the cure of a variety of illnesses and photo-inactivation of bacteria due to absorption of photons in the visible region [7-9]. These compounds are known to be impressive generators of singlet oxygen [10]. One of the most important applications of them is in photodynamic therapy (PDT). The mechanism of singlet oxygen formation by porphyrins involves electronic excitations of their molecules to the first singlet excited state, followed by intersystem crossing with the formation of excited triplet state which is quenched by molecular oxygen. At the end of this sequence, the porphyrin molecule returns to the ground state and singlet oxygen is formed [11-14].

Analysis of the antibacterial activities of a series of porphyrin photo-sensitizers revealed that net charge influences the spectrum of activity. The positively charged polylysine could potentially facilitate binding to the negatively charged bacterial surface, thus allowing the photo-sensitizer to selectively target bacterial cells [1]. Various cationic porphyrins have been used as remarkable antimicrobial agents in PACT [15-20].

In this study, we were considered and compared the effect of meso-tetrakis( $N$-methyl-3pyridyl)porphyrin $\left(\mathrm{TMPyP}_{(3)}\right)$, meso-tetrakis $\left(N\right.$-methyl-4-pyridyl)porphyrin $\left(\mathrm{TMPyP}_{(4)}\right)$ and theirs zinc porphyrin compounds as tetra-cationic porphyrin compounds for consideration of cell death of $S$. aureus and $E$. coli under irradiation with visible light.

\section{Results and Discussion}

The chemical structures of $\mathrm{TMPyP}_{(3)}$ and $\mathrm{TMPyP}(4)$ was shown in figure 1.
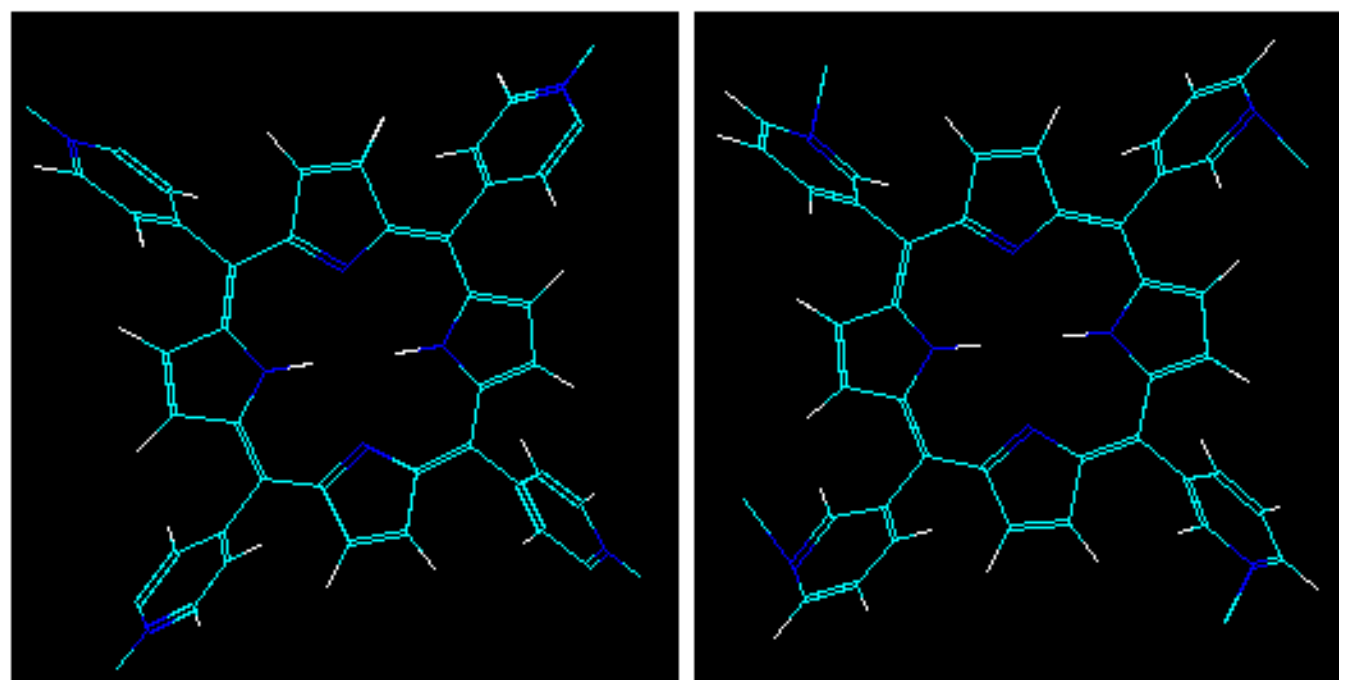

Figure 1. Chemical structure of $\mathrm{TMPyP}_{(3)}$ and $\mathrm{TMPyP}(4)$. left: $\mathrm{TMPyP}(4)$ and right: $\mathrm{TMPyP}_{(3) \text {. }}$ 
Figures 2 and 3 were shown the effect of various concentrations of $\mathrm{TMPyP}_{(3)}$ and $\mathrm{TMPyP}(4)$ against $S$. aureus and E. coli. The percentage of cell death of these compounds was studied against these strains with 30 min illumination.

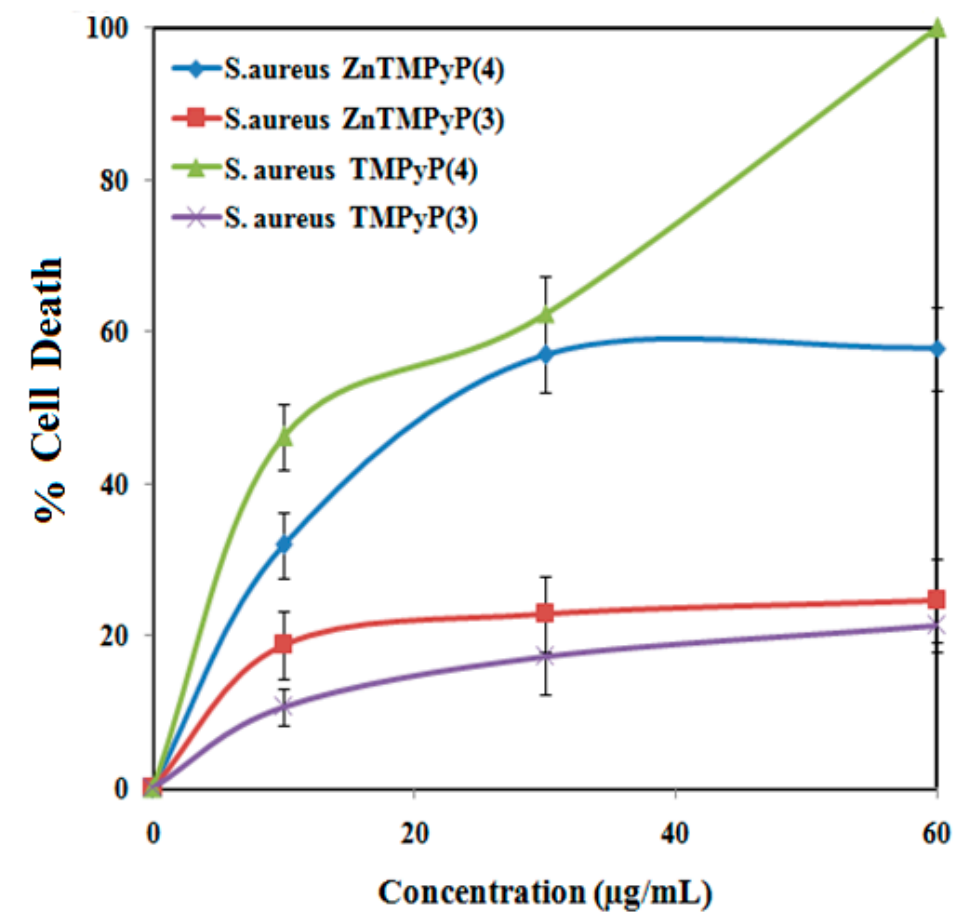

Figure 2. The effect of various concentrations of the studied porphyrin on the $\%$ cell death of $S$. aureus.

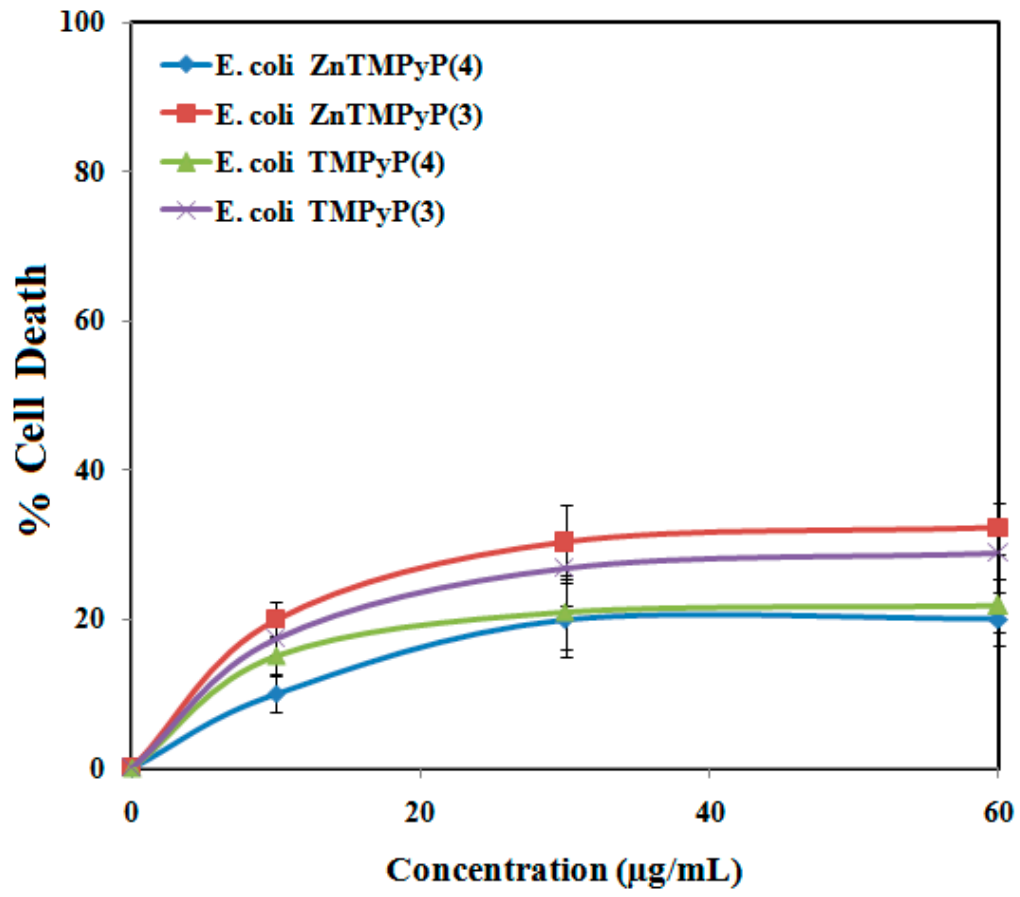

Figure 3. The effect of various concentrations of the studied porphyrin on the $\%$ cell death of E. coli. 
According to figures 2 and 3, the optimum concentration of all compounds was $60 \mu \mathrm{g} / \mathrm{mL}$ against both strains. Increasing in concentration of porphyrins caused to increasing in the percentage of the cell death of the bacteria. TMPyP(4) was shown more cell death than the others against $S$. aureus. It seems that this compound could be attached to this bacterium better than the others. Also, TMPyP(4) and $Z_{\text {ZnTMPyP(4) }}$ had good effects on $S$. aureus attributed to E. coli. The effect of the studied porphyrins against $E$. coli was approximately similar. $\mathrm{TMPyP}_{(3)}$ and its zinc compound were slightly better effect than the others. Both free-porphyrins have similar structure but they have different property in the percentage of cell death of bacteria. It seems, not only incorporation of biocides to bacteria is an important factor but also the molecular structure of biocides is an effective factor in the cell death of microorganisms.

\section{Experimental}

The porphyrins were synthesized and purified in our chemistry laboratory. A 100 Watt tungsten lamp (1250 luman) was used as light source and placed at a distance of $20 \mathrm{~cm}$ from the sample. A plate filled with water was used to absorb heat. This system was setup in a shaker incubator at a rate of $80 \mathrm{rpm}$ in a dark room. S. aureus and E. coli were obtained from the microbiology laboratory of University of Guilan. The both strains were inoculated into nutrient broth and incubated at $37{ }^{\circ} \mathrm{C}$ overnight under aerobic conditions. The stock suspensions were diluted to give a working suspension of approximately $\approx 10^{8}$ colony forming units $/ \mathrm{mL}(\mathrm{CFU} / \mathrm{mL}) .30 \mu \mathrm{L}$ of this cell suspension with various concentrations of porphyrins were added to $2 \mathrm{~mL}$ of nutrient broth and incubated for $20 \mathrm{~min}$ in the dark at $37^{\circ} \mathrm{C}$. Then, the samples were illuminated for $30 \mathrm{~min}$. The percent of cell death of bacteria was determined at the end of the experiment by carrying plate counts of serially diluted samples. Each test was done at least 3 times.

\section{Conclusions}

In this work, the effect of various concentrations of $\mathrm{TMPyP}_{(3)}$ and $\mathrm{TMPyP}_{(4)}$ and theirs zinc compounds were investigated and compared on a Gram positive bacterium, $S$. aureus, and a Gram negative bacterium E. coli under irradiation with a visible light. Our results was shown that $\mathrm{TMPyP}_{(4)}$ was more cell death effect than the others against $S$. aureus. Also, $\mathrm{TMPyP}_{(3)}$ and its zinc compound were slightly better effect than the others against E. coli.

\section{Acknowledgments}

The authors gratefully acknowledge the partial support from the Research Council of the Iran University of Science and Technology.

\section{Conflicts of Interest}

The authors declare no conflict of interest.

\section{References and Notes}

1. Rovaldi, C. R.; Pievsky, A.; Sole, N. A.; Friden, P. M.; Rothstein, D. M.; SpacciapoliP, P. Photoactive Porphyrin Derivative with Broad-Spectrum Activityagainst Oral Pathogens In Vitro. Antimicrobiol Agents Chem. 2000, 3364-3367. 
2. Banfi, S.; Caruso, E.; Buccafurni, L.; Battini, V.; Zazzaron, S.; Barbieri, P.; Orlandi, V. Antibacterial Activity of Tetraaryl-porphyrin Photosensitizers: An in Vitro Study on Gram Negative and Gram Positive Bacteria. J. Photochem. Photob. B: Biol. 2006, 85, 28-38.

3. Cassidy, C. M.; Donnelly, R. F.; Tunney, M. M. Effect of Sub-lethal Challenge with Photodynamic Antimicrobial Chemotherapy (PACT) on the Antibiotic Susceptibility of Clinical Bacterial Isolates. J. Photochem. Photobiol. B: Biol. 2010, 99, 62-66.

4. Latief, M. A.; Chikama, T.; Shibasaki, M.; Sasaki, T.; Ko, J. A.; Kiuchi, Y.; Sakaguchi, T.; Obana, A. Antimicrobial action from a novel porphyrin derivative in photodynamic antimicrobial chemotherapy in vitro, Lasers. Med. Sci. 2015, 30, 383-387.

5. Peèkaitytë, A.; Daugelavièius, R.; Sadauskaitë, A.; Kirvelienë, V.; Bonnett, R.; Bakienë E. Comparative Analysis of the Photobactericidal Action of Selected Tetrapyrrole Compounds on Gram-positive and Gram-negative Bacteria. Biologica. 2005, 41-46.

6. Wainwright, M. Photodynamic antimicrobial chemotherapy (PACT). J. Antimicrob. Chemother. 1998, 42, 13-20.

7. Liu, X.Y.; Wang, H. M.; Jiang, J. Q.; Xiao, J. H.; Gao, R. L.; Lin, F. Y. Porphyrin with Amino Acid Moieties: A Tumor Photosensitizer. Chem.Biol. Interactions. 2008, 172, 154-158.

8. Spesia, M. B.; Lazzeri, D.; Pascual, L.; Rovera, M.; Durantini, E. N. Photoinactivation of Escherichia coli using porphyrin derivatives with different number of cationic charges, FEMS Immunol. Med. Microbiol. 2005, 44, 289-295.

9. Yu, K. G.; Li, D. H.; Zhou, C. H.; Diao, J. L. Study on the synthesis and antimicrobial activity of novel cationic porphyrins. Chin. Chem. Let. 2009, 20, 411-414.

10. Kim, H.; Kim, W.; Mackeyev, Y.; Lee, G-S.; Kim, H-J.; Tachikawa, T.; Hong, S.; Lee, S.; Kim, J.; Wilson, L. J.; Majima, T.; Alvarez, P. J. J.; Choi, W.; Lee, J. Selective Oxidative Degradation of Organic Pollutants by Singlet Oxygen-Mediated Photosensitization: Tin Porphyrin versus C60 Aminofullerene Systems, Environ. Sci. Technol. 2012, 46, 9606-9613.

11. Dosselli, R.; Tampieri, C.; Ruiz-González, R.; Munari, S. D.; Ragàs, X.; Sánchez-García, D.; Agut, M.; Nonell, S.; Reddi, E.; Gobbo, M. Synthesis, Characterization, and Photo induced Antibacterial Activity of Porphyrin-Type Photosensitizers Conjugated to the Antimicrobial Peptide Apidaecin 1b. J. Med. Chem. 2013, 56, 1052-1063.

12. Drogat, N.; Granet, R.; Morvan, C. L.; Bégaud-Grimaud, G.; Krausz, P.; Sol, V. Chlorin-PEI-labeled cellulose nanocrystals: Synthesis, characterization and potential application in PDT, Bioorg. Med. Chem. Let. 2012, 22, 3648-3652.

13. Mordon, S.; Cochrane, C.; Tylcz, J. B.; Betrouni, N.; Mortier, L.; Koncar, V. Light emitting fabric technologies for photodynamic therapy, Photodiag. Photodyn. Therapy. 2015, 12, 1-8.

14. Senthilkumar, S.; Hariharan, R.; Suganthi, A.; Ashokkumar, M.; Rajarajan, M.; Pitchumani, K. Synergistic photodynamic action of $\mathrm{ZnO}$ nanomaterials encapsulated meso-tetra (4-sulfonatophenyl) porphyrin, Powder Tech. 2013, 237, 497-505.

15. Cormick, M. P.; Alvarez, M. G.; Rovera, M.; Durantini, E. N. Photodynamic Inactivation of Candida Albicans Sensitized by Tri- and Tetra-cationic Porphyrin Derivatives. Europ. J. Mineral. 2009, 44, 1592-1599. 
16. Lambrechts, S. A. G.; Aalders, M. C. G.; Verbraak, F. D.; Lagerberg, J. W. M.; Dankert, J. B.; Schuitmaker, J. J. Effect of Albumin on the Photodynamic Inactivation of Microorganisms by a Cationic Porphyrin, J. Photochem. Photobiol. B: Biol. 2005, 79, 51-57.

17. Lazzeri, D.; Durantini, E. N. Synthesis of Meso-substituted Cationic Porphyrins as Potential Photodynamic Agents, ARKIVOC. 2003, 227-239.

18. Nitzan, Y.; Ashkenazi, H. Photoinactivation of Acinetobacter Baumannii and Escherichia Coli B by a Cationic Hydrophilic Porphyrin at Various Light Wavelengths. Current Microbiol. 2001, 42, 408-414.

19. Pudžiuvytè, B.; Daugelavičius, R.; Kirveliene, V.; Sasnauskienė, A.; Bonnett, R.; Bakienè, E. Photodynamic Action of the Cationic Dye tetrakis(N-ethylpyridinium-4-yl)porphyrin Tetratosylate on Escherichia Coli Cell Envelope. Biologija. 2008, 54, 198-201.

20. Reddi, E.; Ceccon, M.; Valduga, G.; Jori, G.; Bommer, J. C.; Elisei, F.; Latterini, L.; Mazzucato, U. Photophysical Properties and Antibacterial Activity of Meso-substituted Cationic Porphyrins, Photochem. Photobiol. 2002, 75, 462-470.

(C) 2015 by the authors; licensee MDPI, Basel, Switzerland. This article is an open access article distributed under the terms and conditions of the Creative Commons Attribution license (http://creativecommons.org/licenses/by/4.0/). 